\title{
Effects of Long-Term Exposure to Air Pollution on Respiratory Function and Physical Efficiency of Pre-Adolescent Children
}

\author{
A. Zebrowska, R. Mankowski
}

Department of Physiological-Medical Sciences, Department of Physiology, Academy of Physical Education, Katowice, Poland

\begin{abstract}
Objectives: The purpose of the present study was to analyze the relationship between the levels of air pollutants and respiratory function/physical efficiency of pre-adolescent children living in the Upper Silesian Industrial Region.

Material and methods: Spirometric evaluations and physical exercise test were performed in 103 children aged 14-16. Standard spirometry was used to analyze: vital capacity (VC), forced vital capacity (FVC), forced expiratory volume in 1 second $\left(\mathrm{FEV}_{1}\right)$, and maximal voluntary volume (MVV). From 1994 through 2008, air pollutants were regularly monitored, and compared with reference ranges.

Results: Differences were noted in the average annual pollutant $\left(\mathrm{SO}_{2}, \mathrm{NO}_{2}, \mathrm{PM}_{10}, \mathrm{CO}\right)$ concentrations during the observation period. Exposure to air pollution was associated with reduced respiratory function and may lead to a decline in physical efficiency in pre-adolescent children.

Conclusions: The pollution-related reduction of lung function in childhood might be related, at least partially, to long-term exposure to particulate air pollutants, and especially in those children who spend more time practicing outdoor sports.
\end{abstract}

Key words: air pollution, pulmonary function, and physical efficiency

\section{INTRODUCTION}

Health effects of exposure to air pollution have been indicated by previous studies suggesting that longterm exposure to ambient particles, nitrogen oxides $\left(\mathrm{NO}_{2}\right)$, and inorganic acid vapor negatively affects the growth in lung function $[1,2]$ and increases the risk of chronic respiratory illness in adulthood [3-5]. It has also been documented that increased concentration of total suspended particulates is a significant predictor of the incidence of upper respiratory symptoms in children [6]. The synergistic effect of sulfur dioxide $\left(\mathrm{SO}_{2}\right)$, particulates, nitrogen oxides $\left(\mathrm{NO}_{\mathrm{x}}\right)$, hydrogen sulfide, and other airborne particles may be a contributing factor in predicting the upper respiratory infections even in those children who live in less polluted areas $[7,8]$.

Most of the studies suggest that elevated air pollution might be associated with reduced expiratory flows $\left(\mathrm{FEV}_{1}, \mathrm{FVC}, \mathrm{MMEF}\right.$, and $\left.\mathrm{FEF}_{75}\right)$, increased frequency of asthma exacerbations, and decreased respiratory performance in children [9-11]. It is suggested that these associations appeared stronger in girls, older children, and in those exposed to parental smoking [2]. The acute health consequences of breathing polluted air may also be more severe in children who have higher ventilation rates than adults, who are more active, and spend more time outdoors [12-14]. However, the effects of long-term exposure to air pollution on respiratory adaptation to physical activity are less clearly defined. In this study, we analyzed the relationship between the levels of air pollutants and respiratory function/physical efficiency of adolescents living in the Upper Silesian Industrial Region.

\section{MATERIAL AND METHODS}

The study conformed to the standards set by the Declaration of Helsinki of 1983 for Human Research and was approved by a Local Ethics Committee of the Academy of Physical Education in Katowice, Poland. The adolescents, enrolled into the study, and their parents were presented with a comprehensive description of the purpose of the study, and written consents from parents were requested and obtained.

A total of 103 (48 girls and 55 boys) healthy adolescents aged 14-16 years volunteered to participate in the study (Table 1). All subjects were living and attending schools in the city of Bytom, one of the most polluted cities in the Upper Silesian Industrial Region. The criteria for inclusion were: no personal history of cardiovascular or metabolic diseases, no medication at the time of the study, and no smoking.

Spirometric evaluations and physical exercise tests were performed at school during morning hours. Standard spirometry (PonyGraphic 3.7, Cosmed, Italy) was used to analyze vital capacity (VC), forced vital capacity (FVC), forced expiratory volume in 1 second $\left(\mathrm{FEV}_{1}\right)$, and maximal voluntary volume (MVV). The measurements were carried out according to spirometric standards for normal children and adolescents. Cardiorespiratory fitness and efficiency were determined using a laboratory test performed on a cycle ergometer (Monark 826, Sweden). The exercise consisted of a submaximal exercise with continuous monitoring of heart rate (HR), and maximal minute oxygen uptake $\left(\mathrm{VO}_{2 \max }\right)$ calculation [15]. A week later, the same participants also performed a running test on the track at the school playground field, the most popular test in 
Table 1. Anthropometric and physiologic characteristics of subjects.

\begin{tabular}{|c|c|c|}
\hline Variable & Male $(\mathrm{n}=55)$ & Female $(\mathrm{n}=48)$ \\
\hline Age (yr) & $15.2 \pm 2.3$ & $15.4 \pm 0.7$ \\
\hline Body height (cm) & $165.0 \pm 25.0$ & $160.1 \pm 6.9^{*}$ \\
\hline Body mass (kg) & $56.4 \pm 14.9$ & $51.4 \pm 9.3$ \\
\hline BMI $\left(\mathrm{kg} / \mathrm{m}_{2}\right)$ & $20.7 \pm 4.2$ & $20.3 \pm 1.5$ \\
\hline VC (L) & $4.1 \pm 0.85$ & $3.0 \pm 0.4^{* *}$ \\
\hline VC (\%pred) & $89.0 \pm 21.5$ & $81.4 \pm 15.8^{*}$ \\
\hline $\mathrm{FEV}_{1}(\mathrm{~L})$ & $3.3 \pm 3.2$ & $2.5 \pm 2.3^{*}$ \\
\hline $\mathrm{EV1}_{1}(\%$ pred $)$ & $78.6 \pm 13.5$ & $75.8 \pm 12.5$ \\
\hline $\mathrm{EV} 1_{1} / \mathrm{VC}(\%)$ & $80.2 \pm 14.4$ & $82.6 \pm 7.8$ \\
\hline $\mathrm{VO}_{2 \mathrm{Max}}(\mathrm{L} / \mathrm{min})$ & $3.3 \pm 0.7$ & $2.9 \pm 0.4^{*}$ \\
\hline MVV (L/min) & $112.0 \pm 35.2$ & $80.4 \pm 19.5^{* *}$ \\
\hline ExT (min) & $3.9 \pm 0.9$ & $2.7 \pm 0.4$ \\
\hline Norm - ExT (L) & $0.3 \pm 0.01$ & $0.2 \pm 0.02$ \\
\hline
\end{tabular}

Data are means $\pm S D$. BMI - body mass index, VC - vital capacity, $\mathrm{FEV}_{1}$ - forced expiratory volume in one second, $\mathrm{VO}_{2 \mathrm{Max}}$ - maximal oxygen uptake, MVV - maximum voluntary volume, ExT - result in exercise test. $* \mathrm{P}<0.05 ; * * \mathrm{P}<0.01$ significant differences between female and male.

the case of school settings. Participants were instructed to complete the distance of 600 meters for girls and 1000 meters for boys as fast as possible. The time of completion was recorded to the nearest second and compared with reference ranges [16].

Ambient air quality was estimated based on the data provided by the State Environmental Monitoring in the Province of Silesia in the years 1993 through 2008. The concentrations of airborne particles and meteorological parameters were measured including wind di- rection and speed, air temperature, relative humidity, total solar radiation, UV radiation, barometric pressure and rainfall. Annual concentrations were determined of the following compounds: sulfur dioxide $\left(\mathrm{SO}_{2}\right)$, nitrogen oxides $\left(\mathrm{NO}_{2}\right)$ carbon oxide (CO), and concentration of suspended particulate matter $\left(\mathrm{PM}_{10}\right)$. Annual reports regarding air quality in urban agglomerations of Silesia were corrected based on diurnal and monthly patterns in the air pollution (Fig. 1). Since the study subjects were inhabitants of Bytom, annual reports were prepared for the city including mean levels of pollution and concentrations exceeding reference ranges in the whole measurement period. Standards for these pollutants are set by the Directive 2008/50/EC of the European Parliament and of the Council of 21 May 2008 'on ambient air quality and cleaner air for Europe'.

Data are presented as means \pm SD. All data were tested for normal distribution and were analyzed with the two-way ANOVA. Significant differences in spirometric values, cardiorespiratory and physical efficiency variables in relation to references ranges were determined using a $t$-test. The relationships between deficits in VC, $\mathrm{FEV}_{1}, \mathrm{MVV}$, and $\mathrm{VO}_{2 \mathrm{Max}}$ were checked by Pearson's correlation coefficient regression analysis. Statistical significance was set at $\mathrm{P}<0.05$.

\section{RESULTS}

We found that long-term exposure to air pollution exerts appreciable effects on respiratory function of adolescent inhabitants of the Upper Silesian Industrial Region. ANOVA revealed a significant influence of high sulfur dioxide $\left(\mathrm{SO}_{2}\right)$ concentrations on $\mathrm{VC}$ deficit, calculated as the difference between measured and reference values $(\mathrm{VCd}=\mathrm{VC}-\mathrm{VCN})(\mathrm{F}=5.46$; $\mathrm{P}<0.01$ ) (Fig. 2A). $\mathrm{SO}_{2}$ concentrations also significant-
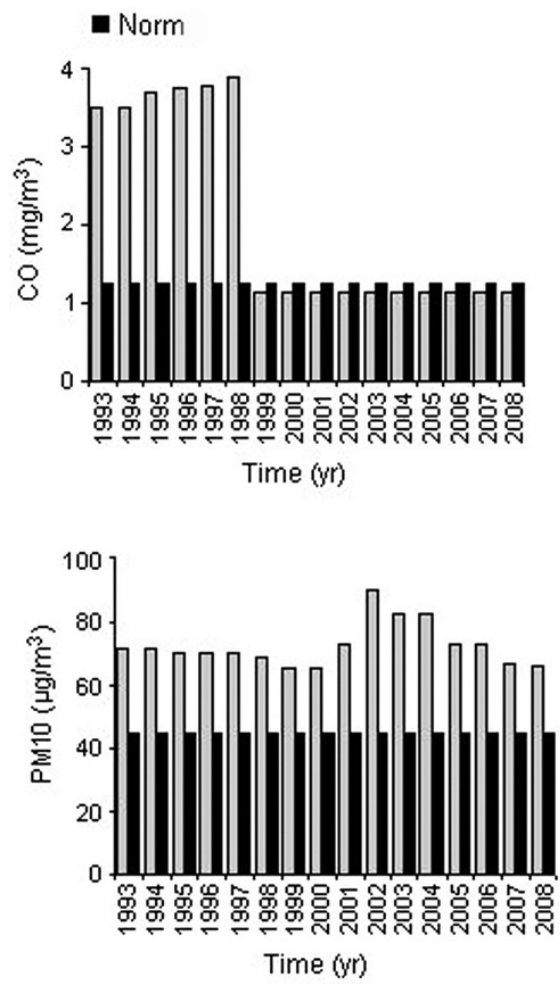
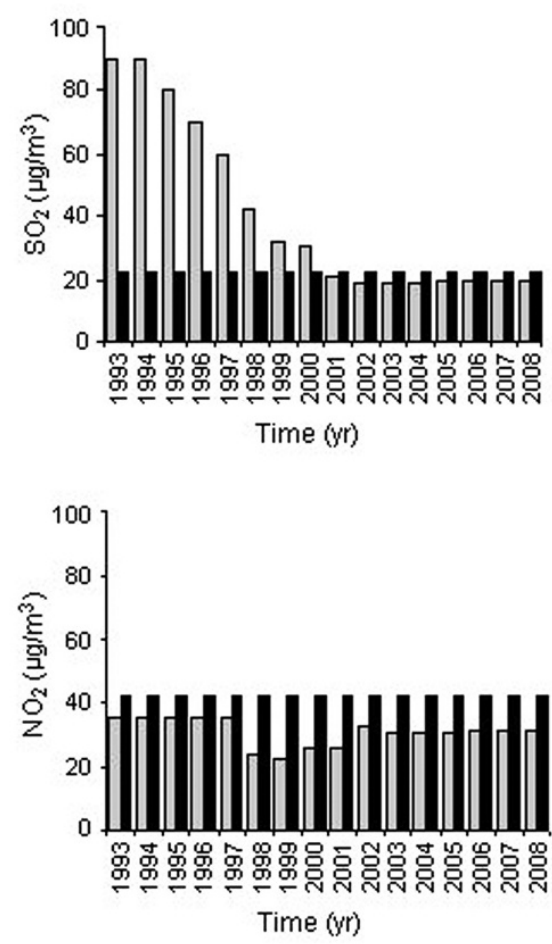

Fig. 1. Average annual pollutant concentrations in the city of Bytom. Filled bars show the norm for each pollutant. 


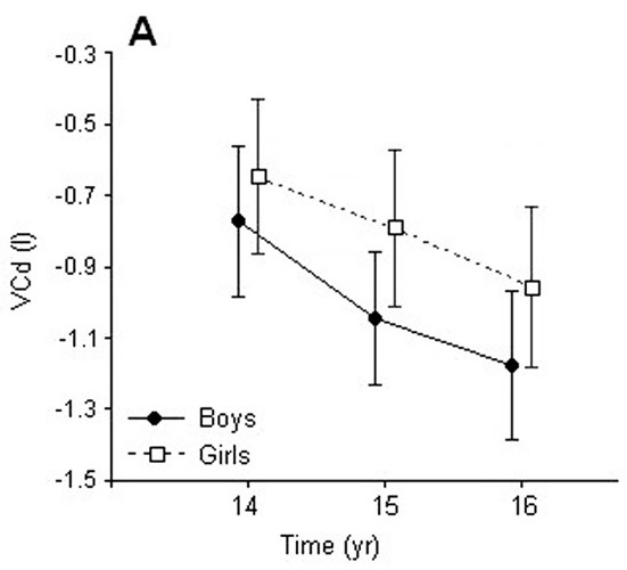

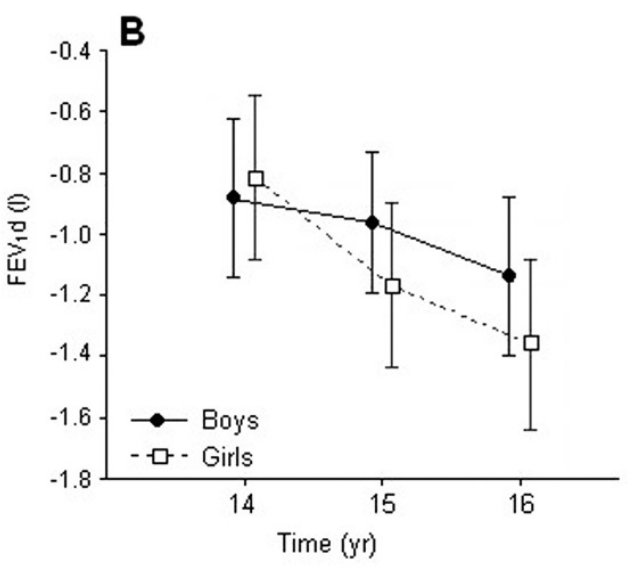

Fig. 2. Duration of exposure to air pollution and vital capacity (VCd, Panel A) and forced expiratory volume in one-second $\left(\mathrm{FEV}_{1} \mathrm{~d}\right.$ (Panel B) deficits in male and female adolescents. ly reduced respiratory function $\left(\mathrm{FEV}_{1} \mathrm{~d} ; \mathrm{F}=4.53\right.$; $\mathrm{P}<0.05)$ (Fig. 2B). Older subjects showed larger deficits in predicted values for $\mathrm{FEV}_{1}$ and $\mathrm{FVC}$ than younger subjects. Similarly, there was a significant effect of increased carbon monoxide (CO) concentration on differences between $\mathrm{VC}$ and $\mathrm{FEV}_{1}$ and the predicted $\mathrm{VC}$ and $\mathrm{FEV}_{1}(\mathrm{~F}=5.25 ; \mathrm{P}<0.01$ and $\mathrm{F}=$ 4.24; $\mathrm{P}<0.05$, respectively). These associations between estimated air pollution exposure and lung function appeared to be significantly stronger in older children; although as expected, no differences were observed between boys and girls $(\mathrm{P}>0.05)$ (Fig. 2A and $\mathrm{B})$.

The mean VC was within normal range (over $80 \%$ predicted value) in $76.9 \%$ of all girls and boys examined. However, $13.1 \%$ of adolescents showed a
VC $<80 \%$ suggesting a restrictive pattern (Table 1). Compared with the reference range, the mean $\mathrm{FEV}_{1}$ was significantly lower in both male and female adolescents exposed to air pollution $(\mathrm{P}<0.01)$. Significant differences in $\mathrm{FEV}_{1}$ were associated with significantly lower value of $\mathrm{FEV}_{1}$ expressed as \%VC. Approximately $6 \%$ of the subjects reported a history of doctor-diagnosed asthma and $12.6 \%$ had symptoms of obstructive pulmonary disease $\left(\mathrm{FEV}_{1}<70 \% \mathrm{VC}\right)$. Differences were noted in average annual concentrations of $\mathrm{SO}_{2}, \mathrm{PM}_{10}$, and $\mathrm{CO}$ with significantly higher air pollution before the year 2000 (Fig. 1). A negative correlation was found between VC deficit and $\mathrm{SO}_{2}$ concentration $(\mathrm{r}=-0.25 ; \mathrm{P}<0.05)$ (Fig. $3 \mathrm{~A})$, and between $\mathrm{FEV}_{1}$ deficit and $\mathrm{SO}_{2}(\mathrm{r}=-0.21 ; \mathrm{P}<0.05)$ (Fig. 3C). The estimated pollution effects of $\mathrm{CO}$ were negatively
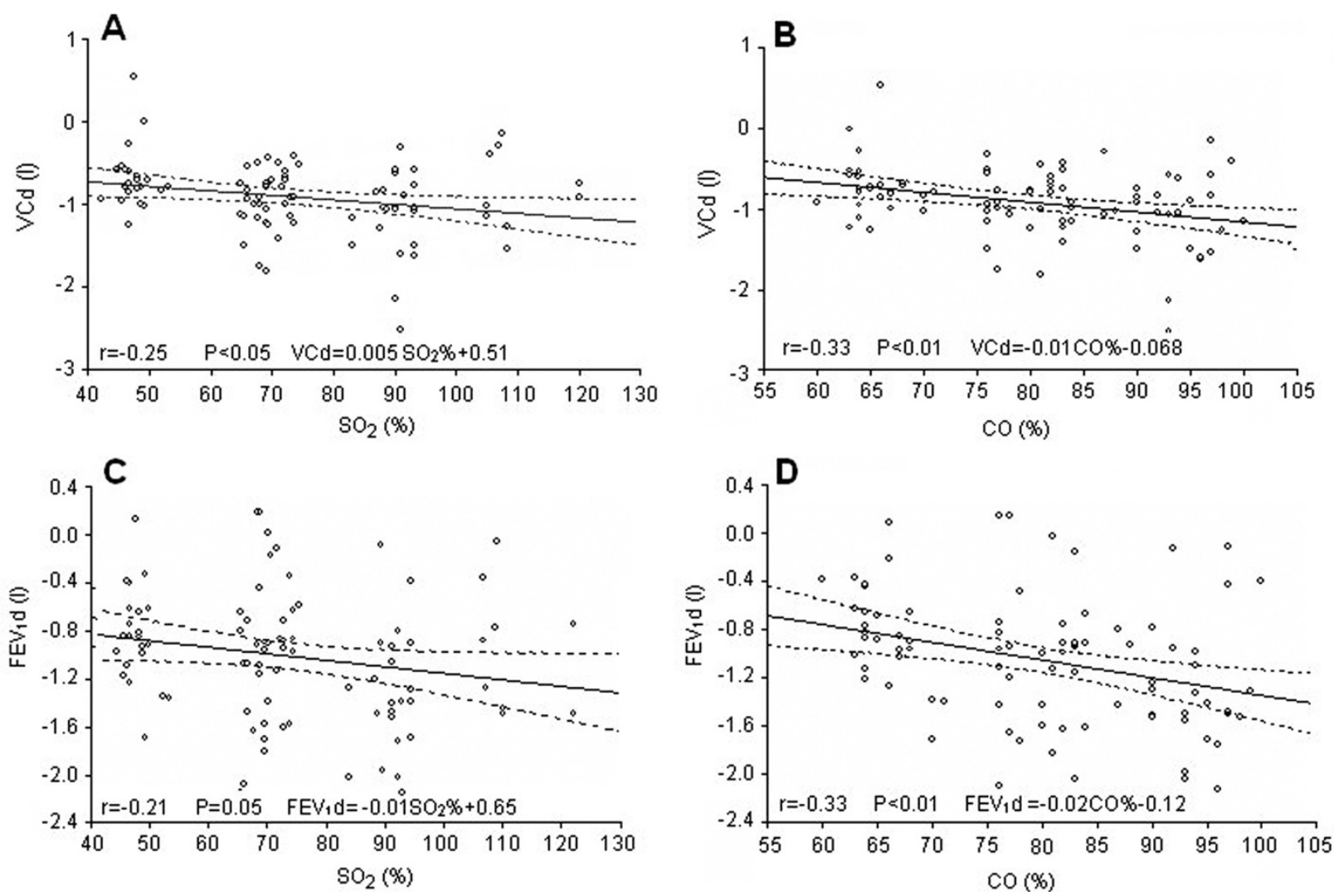

Fig. 3. Correlations between annual percentage increases in sulfur dioxide $\left(\mathrm{SO}_{2}\right)$ (Panels $\mathrm{A}$ and $\left.\mathrm{C}\right)$ and carbon monoxide (CO) (Panels B and D) concentrations and vital capacity $(\mathrm{VCd})$ and forced expiratory volume in one-second $\left(\mathrm{dFEV}_{1} \mathrm{~d}\right)$ deficits. 
correlated with VCd $(\mathrm{r}=-0.33 ; \mathrm{P}<0.01)$ and $\mathrm{FEV}_{1} \mathrm{~d}(\mathrm{r}$ $=-0.32 ; \mathrm{P}<0.01)($ Fig. $3 \mathrm{~B}$ and $\mathrm{D})$.

Exposure to air pollution was associated with reduced results of running exercise tests (Table 1). The values of predicted and measured exercise test results (Norm - ExT) correlated with increased $\mathrm{SO}_{2}$ concentrations $(\mathrm{r}=0.36 ; \mathrm{P}<0.001)$. A significant correlation was observed between $\mathrm{VO}_{2 \mathrm{Max}}$ and $\mathrm{FEV}_{1}(\mathrm{~F}=11.52$; $\mathrm{P}<0.001)$ as well as between $\mathrm{VO}_{2 \mathrm{Max}}$ and MVV ( $\mathrm{r}=$ 0.64; $\mathrm{P}<0.001)$. Interestingly, no correlation was seen between long-term exposure to air pollutants and $\mathrm{VO}_{2 \mathrm{Max}}$.

\section{DISCUSSION}

The data from this research indicate that exposure to air pollution is associated with reduced respiratory function and may lead to physical efficiency decline in children and adolescents. We suggest that pollution-related reduction of lung function in childhood might be related, at least partially, to long-term exposure to particulate air pollutants, and especially in those children who spend more time practicing outdoor sports.

In recent years, much attention has been given to review reports on the early effects of air pollution on health $[2,3,17,18]$. The evidence suggests the effects are the largest in the group under 18 years of age who are more sensitive to the effects of $\mathrm{O}_{3}, \mathrm{SO}_{2}, \mathrm{PM}$, and $\mathrm{NO}_{2}$, and are therefore at risk [4]. It has also been documented that deficits in growth of lung function $\left(\mathrm{FEV}_{1}, \mathrm{FVC}\right)$, maximal mid-expiratory flow (MMEF), and $\mathrm{FEF}_{75}$ were associated with exposure to particles with aerodynamic diameter less than $10 \mu \mathrm{g}\left(\mathrm{PM}_{10}\right)$, $\mathrm{NO}_{2}$, and inorganic acid vapor [6, 7]. Urban air pollution was associated with reduced expiratory flows in schoolchildren aged 9-14 years who lived and attended schools close to heavy-traffic roads $[2,12]$. Cross-sectional studies have also found associations between several pollutants, respiratory infections and asthmatic and allergic symptoms in young children $[2,3,9]$. Synergistic effect of air pollutants $\left(\mathrm{SO}_{2}, \mathrm{PM}, \mathrm{NO}_{\mathrm{x}}\right)$ significantly increased the frequency of upper respiratory infections and the incidence of asthma during the first 4 yrs of live [3]. Our study revealed a high correlation between $\mathrm{SO}_{2}$ and $\mathrm{CO}$ concentrations and a deficit in both vital capacity (VC) and forced expiratory volume in 1 second $\left(\mathrm{FEV}_{1}\right)$ in all examined adolescents; the effects were more pronounced in the oldest participants who had been exposed to $\mathrm{SO}_{2}$ and $\mathrm{CO}$ emission/very high emission already during the first 4 years of life. The present findings of associations between exposure to air pollutants and respiratory symptoms in children are consistent with the results reported in the literature on the subject $[18,20,21]$.

It is worth pointing out that sulfur dioxide $\left(\mathrm{SO}_{2}\right)$ and carbon monoxide (CO) are emitted in a variety of industrial regions [11, 19]. It should be emphasized that Polish air quality standards meet World Health Organization recommendations only recently; before 1998, higher air pollution limits were permissible. The present paper summarizes the data concerning average concentration levels of air pollutants in Bytom, one of the most polluted cities in the Upper Silesian Industrial Region. Some studies found associations between sulfur dioxide $\left(\mathrm{SO}_{2}\right)$ exposure and daily mortality [19]. Asthmatics revealed significant, non-threshold relations between $\mathrm{SO}_{2}$ and decrements in $\mathrm{FEV}_{1}[19,22]$. The health effects of $\mathrm{CO}$ include hypoxia, neurological deficits and neurobehavioral changes and cardiovascular diseases $[17,21]$. The latter seem to develop even an at very low $\mathrm{CO}$ level, which suggests that increased $\mathrm{CO}$ concentrations observed in the present study may have exerted a decremental effect on pulmonary function. Although we did not analyze differences in lung function between children who were spending most of their time outdoors as compared with those who were not, it can be hypothesized that higher concentrations of $\mathrm{SO}_{2}, \mathrm{CO}$, and PM in ambient air were responsible for the observed deficits in lung function. Although analyses of variance showed significant independent effects of each pollutant, some effect of air pollution mixtures cannot be ruled out [11]. We observed no consistent relationships between lung function deficits and $\mathrm{NO}_{2}$, which is a common indoor pollutant. However, earlier analyses revealed lower levels of $\mathrm{FEV}_{1}$ and FVC among children living in homes with high $\mathrm{NO}_{2}$ emission [22]. Other studies on the effect of indoor $\mathrm{NO}_{2}$ on children's lung function suggest some association between respiratory symptoms and $\mathrm{NO}_{2}$, mainly among children with asthma [6]. Short-term exposure to nitrogen dioxide $\left(\mathrm{NO}_{2}\right)$ exposure seems to have a slight negative effect on lung function parameters in children [8, 23]. With long-term exposure, children, but not adults, exhibit increased respiratory symptoms, decreased lung function, and increased incidences of chronic cough, bronchitis, and conjunctivitis [14, 19]. Thus, apart from health effects of breathing polluted air during rest, high ventilation during physical activity may also be implicated in reduced lung growth $[24,25]$. This could occur, for example, if children participate in physical activity lesson in polluted area. Experimental evidence also suggests that the estimated deficits in lung function are generally larger for children spending more time outdoors than in children who spent more time indoors [6]. We can speculate that lower results obtained by our study participants during running tests may be associated with limited pulmonary adaptation or/and depend on high ambient particles concentration in breathing air. Therefore, very active children are more susceptible to the dangers of air pollution.

A major limitation of this study is the lack of a control group from an unpolluted area. A longitudinal study involving a larger number of participants and a suitable control group would be needed to evaluate possible adverse effects of physical activity in areas with high levels of air pollution.

In summary, long-term exposure to air pollution turned out to be associated with deficits in pulmonary function levels. Among children exposed to $\mathrm{SO}_{2}$ and $\mathrm{CO}$ the deficits were large enough to be potentially clinically significant. The observed reduction in lung function may lead to physical efficiency decline in childhood; it may also increase the risk of obstructive lung disease and morbidity associated with low FEV in adulthood. We suggest that pollution-related reduction of lung function in childhood might be related, at least partially, to long-term exposure to particulate air 
pollutants, and especially in those children who spend more time practicing outdoor sports.

Conflicts of interest: No conflicts of interests were declared by the authors in relation to this article.

\section{REFERENCES}

1. Raizenne M, Neas LM, Damokosh AI, Dockery DW, Spengler J, Koutrakis P, Ware JH, Speizer FE. Health effects of acid aerosols on North America children: pulmonary function. Environ Health Perspect 1996; 104 (5): 506-14.

2. Rosenlund M, Forastiere F, Porta D, De Sario M, Badaloni C, Perucci CA. Traffic-related air pollution in relation to respiratory symptoms, allergic sensitization and lung function in school children. Thorax 2009; 64(7): 573-80.

3. Brauer M, Hoek G, Van Vliet P, Meliefste K, Fischer PH, Wijga A, Koopman LP, Neijens HJ, Gerritsen J, Kerkhof M, Heinrich J, Bellander T, Brunekreef B. Air pollution from traffic and the development of respiratory infections and asthmatic and allergic symptoms in children. Am J Respir Crit Care Med 2002; 166(8): 1092-8.

4. Koren HS. Associations between criteria air pollutants and asthma. Environ Health Perspect 1995; 103 Suppl 6: 235-42.

5. Linn WS, Shamoo DA, Anderson KR, Peng RC, Avol EL, Hackney JD, Gong H Jr. Short-term air pollution exposures and responses in Los Angeles area schoolchildren. J Exposure Anal Environ Epidemiol 1996; 6(4): 44972.

6. Gauderman WJ, McConnell R, Gilliland F, London S, Thomas D, Avol E, Vora H, Berhane K, Rappaport EB, Lurmann F, Margolis HG, Peters J. Association between air pollution and lung function growth in Southern California children. Am J Respir Crit Care Med 2000; 162(4): 1383-90.

7. Brauer M, Hoek G, Smit HA, de Jongste JC, Gerritsen J, Postma DS, Kerkhof M, Brunekreef B. Air pollution and development of asthma, allergy and infections in a birth cohort. Eur Respir J 2007; 29 (5): 879-88.

8. Jedrychowski W, Flak E. Effect of air quality on chronic respiratory symptoms adjusted for allergy among preadolescent children. Eur Resp J 1998; 11(6): 312-8.

9. Braun-Fahrländer C, Ackermann-Liebrich U, Schwartz J, Gnehm HP, Rutishauser M, Wanner HU. Air pollution and respiratory symptoms in preschool children. Am Rev Respir Dis 1992; 145(1): 42-7.

10. Cesaroni G, Badaloni C, Porta D, Forastiere F, Perucci CA. Comparison between various indices of exposure to traffic-related air pollution and their impact on respiratory health in adults. Occup Environ Med 2008; 65(10): 683-90.

11. Schwartz J. Lung function and chronic exposure to air pollution: A cross-sectional analysis of NHANES II. Environ Res 1989; 50: 309-21.

12. Brunekreef B, Janssen NA, de Hartog J, Harssema H, Knape M, van Vliet P. Air pollution from truck traffic and lung function in children living near motorways. Epidemiology 1997; 8(3): 298-303.
13. Coates AL, Boyce P, Muller D, Mearns M, Godfrey S. The role of nutritional status, airway obstruction, hypoxia, and abnormalities in serum lipid composition in limiting exercise tolerance in children with cystic fibrosis. Acta Paediatr Scand 2008; 69(3): 353-8.

14. Venn AJ, Lewis SA, Cooper M, Hubbard R, Britton J. Living near a main road and the risk of wheezing illness in children. Am J Respir Crit Care Med 2001; 164(12): 2177-80.

15. Shephard RJ. Tests of maximum oxygen intake. A critical review. Sports Med 1984; 1(2): 99-124.

16. Castro-Pinero J, Ortega FB, Mora J, Sjöström M, Ruiz JR. Criterion related validity of $1 / 2$ mile run-walk test for estimating $\mathrm{VO}_{2}$ peak in children aged 6-17 years. Int J Sports Med 2009; 30(5): 366-71.

17. Chen H, Goldberg MS, Villeneuve PJ. A systemic review of the relation between long-exposure to ambient air pollution and chronic disease. Rev Environ Health 2008; 23(4): 243-97.

18. Gehring U, Wijga AH, Brauer M, Fischer P, Jongste JC, Kerkhof M, Oldenwening M, Smit HA, Brunekreef B. Traffic-related air pollution and the development of asth$\mathrm{ma}$ and allergies during the first 8 years of life. Am J Respir Crit Care Med 2010; 181(6): 596-603.

19. Schwela D. Air pollution and health in urban areas. Rev Environ Health 2000; 15(1-2): 13-42

20. Wang X, Dockery DW, Wypij D, Gold DR, Speizer FE, Ware JH, Ferris BG Jr. Pulmonary function growth velocity in children 6 to 18 years of age. Am Rev Respir Dis 1993; 148(6 Pt 1): 1502-8.

21. Oosterlee A, Drijver M, Lebret E, Brunekreef B. Chronic respiratory symptoms of children and adults living along streets with high traffic density. Occup Environ Med 1996; 53(4): 241-7

22. Ware JH, Ferris BG, Dockery DW, Spengler JD, Stram DO, Speizer FE. Effects of ambient sulfur oxides and suspended particles on respiratory health of pre-adolescent children. Am Rev Respir Dis 1986; 133(5): 834-42.

23. Kim JJ, Smorodinsky S, Lipsett M, Singer BC, Hodgson AT, Ostro B. Traffic-related air pollution near bus roads: the East Bay Children's Respiratory Health Study. Am J Respir Crit Care Med 2004; 170(5): 520-6.

24. Ortega FB, Ruiz JR, Castillo MJ, Sjöström M. Physical fitness in childhood and adolescence: a powerful marker of health. Int J Obes (Lond) 2008; 32(1): 1-11.

25. Taylor HL, Buskirk E, Henschel A. Maximal oxygen intake as an objective measure of cardio-respiratory performance. J Appl Physiol 1955; 8(1): 73-80.

Address for correspondence:

Aleksandra Zebrowska

Academy of Physical Education

72A, Mikolowska St.

40-065 Katowice

Poland

Phone: +48 32-2075144; mobile +48 608418581

E-mail: a.zebrowska@awf.katowice.pl 